\title{
Hawkweed invasion does not prevent indigenous non-forest vegetation recovery following grazing removal
}

\author{
Susan Walker ${ }^{*}$, Joy Comrie ${ }^{2}$, Nicholas Head ${ }^{3}$, Kate J. Ladley ${ }^{1,4}$ and Dean Clarke ${ }^{1,5}$ \\ ${ }^{1}$ Landcare Research, Private Bag 1930, Dunedin 9054, New Zealand \\ ${ }^{2}$ Te Manahuna / Twizel Office, Department of Conservation, Private Bag, Twizel 7944, New Zealand \\ ${ }^{3}$ Ōtautahi / Christchurch Office, Department of Conservation, Private Bag 4715, Christchurch 8140, New Zealand \\ ${ }^{4}$ Present address: Hokitika Office, Department of Conservation, Private Bag 701, Hokitika 7842, New Zealand \\ ${ }^{5}$ Present address: Te Papaioea / Palmerston North Office, Department of Conservation, Private Bag 11010, \\ Palmerston North 4442, New Zealand \\ *Author for correspondence (Email: walkers@landcareresearch.co.nz)
}

Published online: 23 September 2015

\begin{abstract}
Factors controlling vegetation restoration of depleted short-tussock grasslands are poorly understood. We investigated effects of mouse-ear hawkweed ('hawkweed', Pilosella officinarum) cover and environmental stress associated with landform and soil type on the rate and pattern of indigenous vegetation recovery from grazing in the highly-modified 1000-ha Lake Tekapo Scientific Reserve in the north of the Upper Waitaki ('Mackenzie') Basin. The reserve has been destocked of sheep and under effective rabbit control since 1992. At that time, mouse-ear hawkweed dominated vegetation on three of its five major landforms (up to $42 \%$ cover), and 44-89\% of soil was exposed. In 2011 we resampled 12 original vegetation monitoring plots that were established in 1993. Indigenous vegetation recovered in the 18 years following removal from grazing despite high levels of initial modification and exotic cover dominance. Exposed soil and rock decreased, and indigenous plant cover and litter increased across all landforms, while vascular and nonvascular indigenous plant cover increased at different ends of a landform-driven productivity gradient. Hawkweed invasion did not retard recovery; to the contrary, the extent and rate of recovery was higher on more productive landforms with higher initial hawkweed cover. The pattern of change across the reserve was consistent with grazing having exerted a powerful constraint on the growth and biomass of both indigenous and exotic palatable species prior to reservation. Soil moisture stress appeared to delay the timing of hawkweed invasion, and to constrain productivity and hence the rate of indigenous vegetation recovery following release from grazing. We propose a testable model of interacting influences of grazing and environment on indigenous vegetation and the niche of mouse-ear hawkweed, in which recovery outcomes depend on environmental productivity. We suggest that removal of feral grazing as well as stock, size of recovery area, limited monitoring-disturbance, and timing of grazing-release relative to hawkweed invasion may explain why our results and conclusions contrast with those from other studies of release of fescue-tussock grasslands from pastoral grazing.
\end{abstract}

Keywords: conservation management; glacially-derived landforms; long-term monitoring; plant competition; productivity gradient; temperate indigenous grassland rehabilitation; restoration; weed invasion

\section{Introduction}

Non-indigenous plant species can interfere with efforts to restore plant communities by altering successional processes that would otherwise lead to more desirable vegetation assemblages and conditions (D’Antonio \& Meyerson 2002). However, effects of introduced species on resident communities are context-dependent and partly determined by interactions between species traits and the biome invaded (Pyšek et al. 2012). Competitive interactions between introduced and resident species in succession are also affected by a site's productivity; competitive exclusion is more common in more productive sites, and facilitation and coexistence are more common at resource-limited sites (Callaway 2007; Davies et al. 2007).

Mouse-ear hawkweed (Pilosella officinarum ${ }^{1}$ Vaill., Asteraceae, formerly Hieracium pilosella, common name 'mouse-ear hawkweed', hereinafter referred to as 'hawkweed')

${ }^{1}$ Nomenclature follows preferred plant names in Ngā Tipu o Aotearoa New Zealand Plants (http://nzflora.landcareresearch.co.nz) is a highly invasive, largely unpalatable flatweed that presently dominates the ground cover of most of New Zealand's remaining montane-subalpine short-tussock grasslands (Mark \& McLennan 2005; Day \& Buckley 2013). It is an important pastoral weed because it is avoided by sheep, and its invasion is linked to declining feed availability (Scott 1984). Land managers are concerned that hawkweed may also compromise the persistence and recovery of indigenous grassland species, and are uncertain whether establishment of protected areas and common conservation management practices (e.g. destocking, and control of rabbits and wilding conifers) will maintain or enhance indigenous grassland biota in grasslands invaded by hawkweed. These concerns are supported by results of some exclosure and retirement studies in fescue tussock grasslands. For example, some studies have found little effect of grazing exclusion on grassland recovery in the Upper Waitaki Basin (Meurk et al. 2002) and inland Marlborough (Rose \& Frampton 2007), and short native grasses have declined and hawkweed increased in blocks retired from stock (but not feral herbivores) in the 1960s, as well as in those continuously grazed in the 
Wairau and Harper-Avoca catchments (Rose et al. 1995, 2004). However, few studies have investigated changes in short-tussock grasslands within relatively large areas that have been protected from both stock and feral grazing at an advanced stage of hawkweed invasion.

Some of the most extensive, modified and invaded shorttussock grasslands in New Zealand occur today on the glacially derived floor of New Zealand's Upper Waitaki ('Mackenzie') Basin, in the eastern rain shadow of the Southern Alps. In 2011, we remeasured a set of 12 permanent monitoring plots $(20 \times 20 \mathrm{~m})$ that were established and first measured in 1993 within the then newly gazetted and recently destocked Lake Tekapo Scientific Reserve (LTSR). The reserve is one of the largest on the floor of the Upper Waitaki Basin and today has the longest (now $>20$-year) record of management with low rabbit numbers $(<1$ per spotlight-km) and without stock grazing. It covers five different landforms with different soil types and moisture-holding properties, providing a natural gradient from highly stressful to somewhat more productive edaphic environments. In 1993, the vegetation was exceptionally modified, to the extent that hawkweed invasion and depletion of short tussocks on the main landforms provoked local debate over the suitability of the establishment of a reserve for conservation (Espie 1997) (Fig. 1).

Here, we use repeated measures from the permanent plots to test the hypotheses that recovery of indigenous short-tussock grassland vegetation following cessation of grazing will be retarded by (1) hawkweed invasion and (2) environmental stress associated with landform and soil type. We also scrutinise two long-held alternative views of hawkweed invasion in New Zealand grasslands (Rose et al. 1998). If hawkweed is an aggressive competitive invader that displaces indigenous species (the view of Scott 1984), high hawkweed cover should have impeded grassland recovery from grazing in LTSR.

\section{River terrace (foreground, Plot 9, view southeast) and escarpment behind}

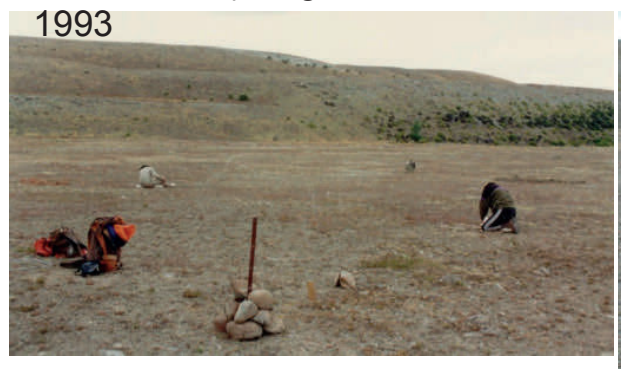

Outwash plain (Plot 4, view northwest) 1993

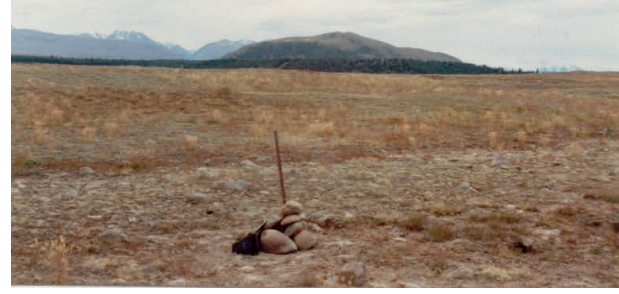

Moraine (Plot 11, view northeast) 1993

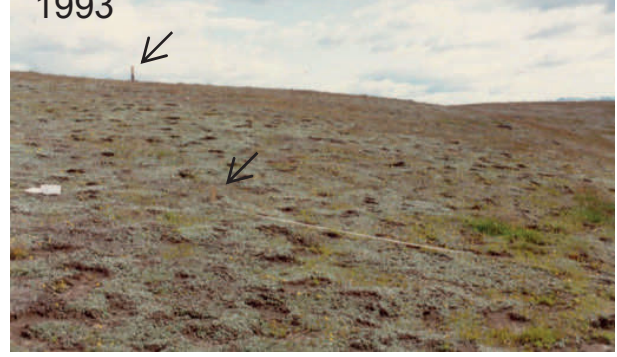

Moraine fan (Plot 3, view south)

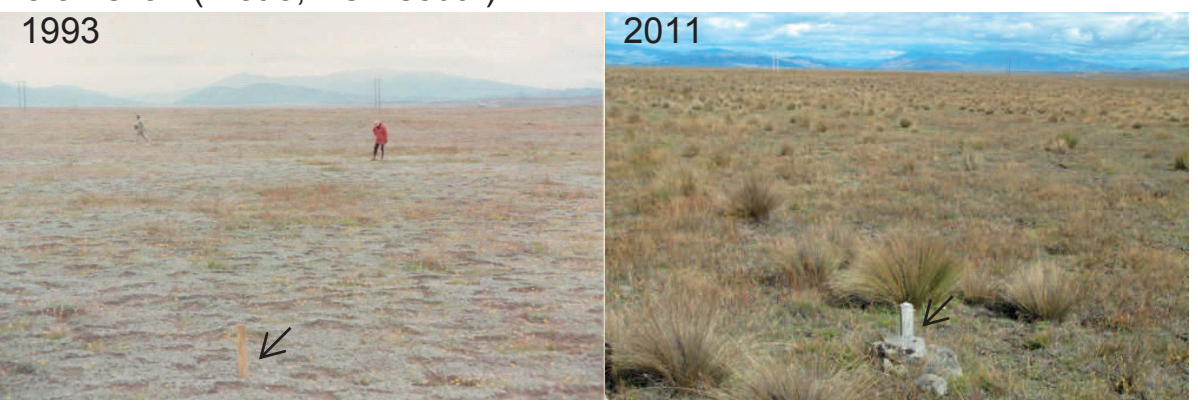

2011

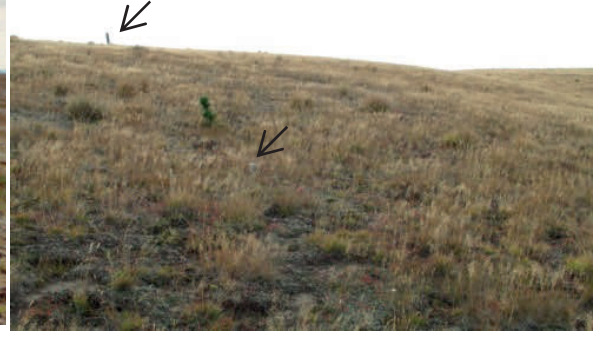

\section{1}

K

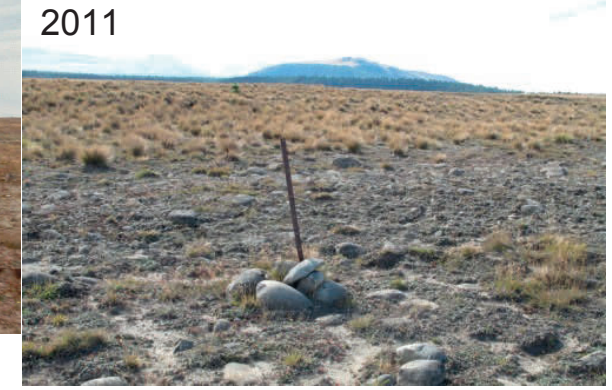
2011

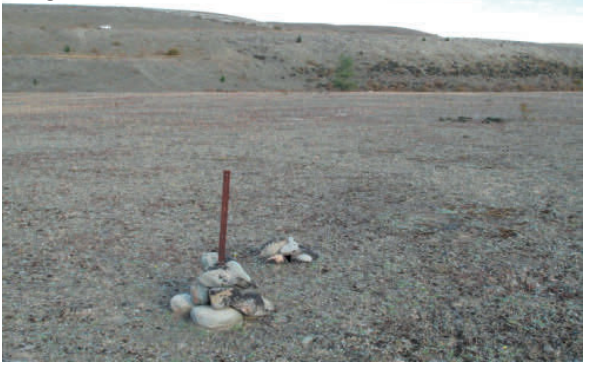

2011
Figure 1. Photographs taken at vegetation plots on four of the five landforms in Lake Tekapo Scientific Reserve (LTSR) in 1993 and 2011. Arrows indicate positions of permanent reference marker pegs at plots 10 and 3 . 
Alternatively, if grazing depletes indigenous species and hawkweed invasion is a symptom of grassland degradation under pastoral land use (e.g. Treskonova 1991; Duncan et al. 1997), vegetation recovery might be limited by abiotic factors, but not by hawkweed.

We use our results to propose a testable model of the interacting influences of grazing and productivity to predict recovery of indigenous short-tussock grassland vegetation in the presence of hawkweed on glacial and alluvial landforms in the Upper Waitaki Basin. The model incorporates common ecological trade-offs, especially that competition increases (Grime 1979; van der Wal et al. 2000) and switches from primarily below-ground to above-ground with increasing site productivity (Tilman 1988), and grazing pre-empts competition from palatable plant species by asymmetrically suppressing their biomass and population sizes (Louda et al. 1990; Huntly 1991).

\section{Methods}

\section{Study area}

Lake Tekapo Scientific Reserve covers 1058 ha between 660 and $790 \mathrm{~m}$ elevation south of Lake Tekapo in the South Island's Upper Waitaki Basin (Fig. 2). It has a cool dry climate, with short summers, a mean annual temperature of $8.5^{\circ} \mathrm{C}$, and average daily temperatures of $14.7^{\circ} \mathrm{C}$ in January and $1.7^{\circ} \mathrm{C}$ in July. Mean annual rainfall across the reserve is $660 \mathrm{~mm}$ and the mean summed monthly annual moisture deficit is $590 \mathrm{~mm}$ (Leathwick et al. 2003). Strong, desiccating, northwesterly föhn winds are common, especially in spring and autumn. The present vegetation includes depleted shorttussock grassland and herbfield (cushion and mat) vegetation, and a little shrubland on scarps.

The reserve's highest land in the north is hummocky Mt John moraine (Barrell et al. 2011) with well- to excessivelydrained Tekapo and Mary series soils (Webb 1992) (Table 1). South of the moraine is a 'moraine fan' (or 'moraine apron') characterised by Tekapo series soils, which are deeper, finer and less rocky that those of the moraine. The fan slopes southward to an extensive outwash plain with a surface pattern of channels and aeolian risers and associated variability in the depth of its Fork series soils. Channel soils on this surface are stony and stripped of topsoil, while the narrower risers have deeper profiles of fine aeolian deposits. The terrace of the Tekapo River lies to the west of the plain, and has stonefields and skeletal Bendrose and Larbeck series soils over a subdued surface topography of dry channels and risers. The plain and terrace are separated by a series of steep, bouldery, north-west-facing scarps up to $40 \mathrm{~m}$ high (collectively 'the escarpment'), also with Bendrose and Larbeck soils.

\section{Plot placement, sampling and data handling}

The 12 original permanent plots $(20 \times 20 \mathrm{~m})$ were established and first sampled in the reserve in 1993 (Espie 1997). They are distributed among the five recognised landforms as follows: moraine (3 plots), moraine fan (1 plot), outwash plain (4 plots), escarpment ( 2 plots), river terrace ( 2 plots) (Fig. 2; Table 2). We are not confident that plots were randomly located, and

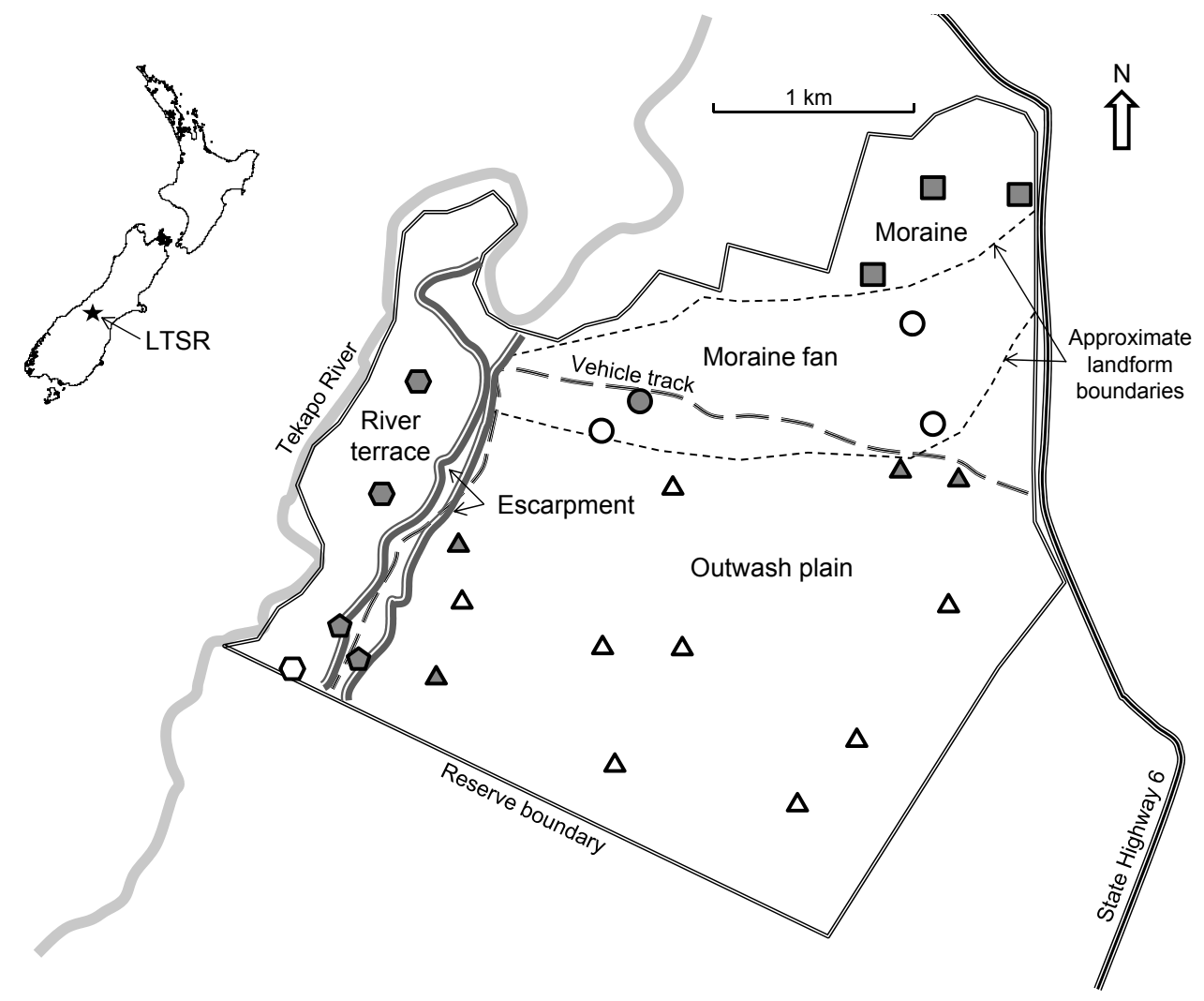

Figure 2. Location and plan of Lake Tekapo Scientific Reserve (LTSR) showing the main geographic and landform features and boundaries. Original plots (established 1993) are indicated as grey symbols (moraine as squares, moraine fan as circles, outwash plain as triangles, river terrace as hexagons and escarpment as pentagons). Unfilled symbols represent new plots (established in 2011). 
Table 1. Characteristics of soil series represented in Lake Tekapo Scientific Reserve (LTSR) as recorded in Webb (1992).

\begin{tabular}{|c|c|c|c|c|c|c|c|}
\hline \multirow{2}{*}{ Soil series } & \multirow{2}{*}{ Soil of } & \multirow{2}{*}{ Drainage } & \multirow{2}{*}{ Horizons } & \multirow{2}{*}{$\begin{array}{l}\text { Stoneless depth } \\
\quad(\mathrm{cm})\end{array}$} & \multicolumn{3}{|c|}{ Properties of solum } \\
\hline & & & & & Thickness $(\mathrm{cm})$ & Texture of fines & Stone weathering \\
\hline Tekapo & Moraines & Well drained & $\mathrm{A}, \mathrm{Bw}, \mathrm{C}$ & $>20$ & $>50$ & $\begin{array}{l}\text { Fine sandy loam } \\
\text { or fine sand } \\
(<18 \% \text { clay })\end{array}$ & Weak \\
\hline Mary & Moraines & $\begin{array}{l}\text { Excessively } \\
\text { drained }\end{array}$ & $\mathrm{A}, \mathrm{Bw}, \mathrm{C}$ & $<20$ & $<40$ & $\begin{array}{l}\text { Sandy loam } \\
\text { or loamy sand }\end{array}$ & Weak \\
\hline Fork & $\begin{array}{l}\text { Intermediate } \\
\text { terraces and } \\
\text { fans }\end{array}$ & $\begin{array}{c}\text { Excessively } \\
\text { drained }\end{array}$ & $\mathrm{A}, \mathrm{Bw}, \mathrm{Bh}, \mathrm{C}$ & Variable & $<50$ & $\begin{array}{l}\text { Sandy loam } \\
\text { or loamy sand }\end{array}$ & Weak \\
\hline Larbeck & $\begin{array}{l}\text { Young terraces } \\
\text { and fans }\end{array}$ & $\begin{array}{l}\text { Excessively } \\
\text { drained }\end{array}$ & $\mathrm{A}, \mathrm{Bw}, \mathrm{C}$ & Variable & $<40$ & $\begin{array}{l}\text { Sandy loam } \\
\text { or loamy sand }\end{array}$ & Weak \\
\hline Bendrose & Floodplains & $\begin{array}{l}\text { Well to } \\
\text { excessively } \\
\text { drained }\end{array}$ & $\mathrm{A}, \mathrm{C}$ & Variable & $<40$ & $\begin{array}{l}\text { Sandy loam } \\
\text { or loamy sand }\end{array}$ & Nil \\
\hline
\end{tabular}

Table 2. Characteristics of short-tussock grassland plots in landform groups at Lake Tekapo Scientific Reserve (LTSR). 'Initial' cover was recorded in 1993.

\begin{tabular}{|c|c|c|c|c|c|c|c|c|c|}
\hline \multirow[t]{2}{*}{ Landform } & \multirow[t]{2}{*}{ Age } & \multirow[t]{2}{*}{ Soil series } & \multirow{2}{*}{$\begin{array}{c}\text { Average } P \\
\text { elevation } \\
{[\min , \max ]}\end{array}$} & \multirow{2}{*}{$\begin{array}{l}\text { Productivity } \\
\text { rank }\end{array}$} & \multirow{2}{*}{$\begin{array}{c}\text { Percent of } \\
\text { LTSR } \\
\text { area }\end{array}$} & \multirow{2}{*}{$\begin{array}{c}\text { Number of } \\
\text { original } \\
\text { plots }\end{array}$} & \multirow{2}{*}{$\begin{array}{c}\text { Original } \\
\text { plot } \\
\text { weighting }\end{array}$} & \multicolumn{2}{|c|}{ Average initial $\%$ cover $[\min , \max ]$} \\
\hline & & & & & & & & Hawkweed & Exposed soil or rock \\
\hline River terrace & Holocene & Bendrose-Larbeck & $675[660,690]$ & 1 & 7 & 2 & 0.29 & $0[0,0]$ & $88.8[86.6,90.9]$ \\
\hline Escarpment & Holocene & Bendrose-Larbeck & $700[680,720]$ & 2 & 2 & 2 & 1.00 & $2.1[0.8,3.5]$ & $77.9[75.3,80.6]$ \\
\hline Outwash plain & Late Otira & Fork & $725[705,755]$ & 3 & 61 & 4 & 0.07 & $16.1[10.6,23.2]$ & $62.5[46.6,75.8]$ \\
\hline Moraine & Late Otira & Tekapo-Mary & $760[720,770]$ & 4 & 12 & 3 & 0.25 & $41.6[36.9,47.4]$ & $43.9[37.6,49.6]$ \\
\hline Moraine fan & Late Otira & Tekapo & $745[725,760]$ & 5 & 18 & 1 & 0.06 & 42.3 & 44.8 \\
\hline
\end{tabular}

one plot thought by Espie (1997) to lie on the moraine fan has characteristic Fork soils and was classified as an outwash-plain plot in our analyses.

For analysis, we assigned each landform a productivity rank on the basis of soil characteristics and moisture deficit (moraine fan $=5$ [highest], moraine $=4$, outwash plain $=3$, escarpment $=2$, terrace $=1$ [lowest]). The productivity of basin-floor soils is primarily determined by profile-available water (correlated with soil depth and texture) and secondarily by climatic moisture balance (Webb 1992, p. 68). Hence the deepest and least stony Tekapo soils of the moraine fan represent the reserve's most productive edaphic environment, and the Bendrose/Larbeck escarpment and terrace soils are the least productive (Table 2). This edaphic productivity gradient is reinforced by the local pattern of climatic moisture balance across the reserve. Penman moisture deficits estimated from climate surfaces (Leathwick et al. 2003) are lowest at moraine and moraine fan plots (575-585 $\mathrm{mm}$ per annum) and highest on the river terrace (average $645 \mathrm{~mm}$ per annum).

In 1993, eight subsamples (quadrats of $0.5 \times 0.5 \mathrm{~m}$ ) were measured within each plot. Quadrat centres were located at the coordinates specified in Allen et al. (1983) and Wiser \& Rose (1997), which were permanently marked with aluminium pegs. In each quadrat, the cover of each vascular plant species present was visually estimated and recorded, and the ground cover of lichens, mosses, bare (exposed) soil, exposed rock, and litter were also estimated. A metal quadrat frame $(0.5 \times 0.5$ $\mathrm{m})$, subdivided into 25 subquadrats $(10 \times 10 \mathrm{~cm})$, was used to assist visual estimation. We repeated this eight-quadrat method in each of the 12 original plots in January 2011.
We averaged percent cover of each vascular plant species and ground cover variable across the eight subsamples in each plot and sampling year (1993 or 2011) for analyses, as our interest was in community-scale and not subplot-scale recovery.

The 74 vascular plant species recorded in one or both years were categorised as either exotic or indigenous. They were further categorised into one of four exotic and twelve indigenous 'life form groups' with similar morphological traits, which are potential predictors of species' competitive abilities and outcomes in response to environmental change (Gaudet \& Keddy 1988). The exotic plant life form groups were (1) dicot composite herb (i.e. eudicot non-woody plant in the family Asteraceae, which in our data entirely comprised Pilosella species or hawkweeds); (2) dicot non-composite herb; (3) grass; and (4) tree or shrub. The indigenous plant life form groups were (1) cushion-forming dicot composite herb; (2) erect dicot composite herb; (3) dicot non-composite herb; (4) tussock grass; (5) xerophytic dwarf grass; (6) other grass; (7) orchid; (8) rush; (9) sedge; (10) erect subshrub; (11) cushion- or mat-forming subshrub; and (12) erect shrub. We calculated the summed cover of species in each life-form group in each plot and sampling year.

\section{Data analyses}

Approach

The original monitoring and sampling design limits our options for data analyses. No grazed experimental control exists to distinguish effects of conservation management from background changes. Plot replication on each landform was 
low, providing low statistical power, and landform plot-to-area weightings were unequal, ranging from 1.00 on the narrow escarpment (where two plots represent 2\% of the reserve's total land area) to 0.06 on the moraine fan (where one plot represented a landform covering $18 \%$ of the reserve's total area; Table 1). The subsampling method records fewer than half the vascular plant species present per plot, with a bias towards detecting exotic species, which are more abundant and spatially dispersed than indigenous species (Walker et al. 2015; see this issue). We therefore focus our analyses on patterns of change in dominant plant species and groups along gradients of environmental productivity (derived from the productivity ranks of the five landforms) and initial hawkweed cover, and combine the insights provided with well-known ecological trade-offs to propose a model of the system. We used the software R v.3.10.1 (R Core Team 2014) for all analyses.

\section{Changes in species and life-form groups along a productivity gradient}

To look for differences in vegetation change among the five landforms, we first classified a change table of species recorded in one or both sampling years (rows; with aggregated mosses and lichens included as two additional 'species') by 12 plots (columns). Table cell entries were the natural log of the change ratio ('LCR'; $\ln \left(t_{2}+0.01\right) /\left(t_{1}+0.01\right)$, where $t_{1}$ and $t_{2}$ are cover in 1993 and 2011, respectively), which enabled comparisons of cover changes among species with different natural abundance. We used hierarchical clustering to group species and plots showing similar changes by applying the $\mathrm{R}$ function 'hclust' (selecting the unweighted-pair-group method with an arithmetic mean; Legendre \& Legendre 2012). Next, we plotted the direction and magnitude of changes in the species in life-form groups across the landform productivity gradient to assess whether changes in these groups varied with productivity rank.

\section{Indigenous vegetation recovery and exotic cover change along productivity and hawkweed-invasion gradients}

To test our hypotheses that environmental stress and/or hawkweed invasion would retard recovery, we fitted linear mixed-effects models to explain each of six indicators of vegetation recovery between 1993 and 2011: (a) exposed soil and rock, (b) litter, (c) indigenous tussock grasses (Festuca novae-zelandiae and Poa colensoi), (d) total indigenous plant cover (i.e. of vascular and non-vascular plants), (e) indigenous vascular plant cover and (f) indigenous cover dominance (i.e. the indigenous proportion of total plant cover). We would interpret a decrease in exposed soil and rock (a) and an increase in litter (b) to reflect post-pastoral successional recovery in the vegetation, and improvements in the cover and dominance of indigenous plant species components ( $c$ to $f$ ) to be recovery consistent with the reserve's conservation purpose.

Two separate models were fit for each indicator, one with initial hawkweed cover and the other with productivity rank as a predictor. This was because productive landforms were initially more invaded, so that productivity and initial hawkweed cover were strongly positively correlated $(r=0.9$; i.e. true relationships will be masked if both are included in a single model, and each has low independent explanatory power). In each model, plot was a random effect and fixedeffect predictors were sampling year, and either landform productivity rank (as a continuous variable) or the cover of Pilosella officinarum in 1993 ('initial hawkweed'), and the year $\times$ productivity rank or year $\times$ initial hawkweed interaction. Significant interaction effects in these models would indicate that temporal change in the response variable varied with landform productivity or initial hawkweed cover.

Each predictor was centred prior to model fitting. Litter, tussock and indigenous plant cover response variables were square-root-transformed for analysis, and indigenous cover dominance was transformed by taking the arcsine of the proportion's square root. We checked each model graphically for conformity with model assumptions, including homoscedacity of residuals. To assess the statistical significance of effects, we calculated $95 \%$ highest posterior density intervals (HPDI) for each coefficient from 1000 draws from the posterior distribution (Plummer et al. 2006). To show visually how the predictors combine to influence each response variable, effects were averaged across other terms in the model and plotted (Fox 2003).

We used the same model structure and procedure as described for recovery indicators to compare changes in exotic grass and hawkweed cover across productivity and initial hawkweed gradients.

\section{Results}

\section{Changes in species groups}

Our change classification (Fig. 3) distinguished eight major groupings of plants (Species Groups A to H in Fig. 3) and three major groupings of plots (Plot Group 1: river terrace and escarpment plots; Plot Group 2: outwash plain plots; and Plot Group 3: moraine and moraine fan plots). These Plot Group divisions indicate that community changes between 1993 (soon after mammalian grazing was removed) and 2011 varied with landform productivity.

Changes in some species were common to all landforms. The exotic grass Anthoxanthum odoratum and lichens (Species Group A) increased in cover on all landforms (maximum increases $7.7 \%$ and $33.2 \%$ cover, and median changes $0.6 \%$ and $2.6 \%$, respectively). In contrast, exotic annual herbs Erophila verna, Myosotis discolor, and Veronica arvensis, the exotic grass Poa pratensis, three indigenous dwarf grasses (Agrostis muscosa, Poa maniototo and P. lindsayi) and the xerophytic indigenous herb Stellaria gracilenta in Species Group $\mathrm{G}$ decreased on all landforms (median cover $0.04 \%$ in 1993 and $<0.01 \%$ in 2011) (Fig. 3).

Several indigenous species (in Species Groups $\mathrm{C}$ to $\mathrm{F}$ in Fig. 3) generally increased in cover on the three more productive landforms (outwash plain, moraine and/or moraine fan, i.e. Plot Groups 2 and 3). These included the sedge Carex breviculmis, herbs Leucopogon nanum and Stackhousia minima, and the grass Anthsacne falcis (species group C in Fig. 3; maximum increase $4.9 \%$ and median change $0.2 \%$ ). Tussocks of Festuca novae-zelandiae ('fescue tussocks') and the herb Celmisia gracilenta (species group D) increased in outwash plain and moraine fan plots (maximum increases $13.0 \%$ and $0.9 \%$, median changes $1.8 \%$ and $0.3 \%$, respectively). Fescue tussocks were also present in the larger $20 \times 20 \mathrm{~m}$ moraine plots in 2011 but are not shown in Figure 3 because the eight $0.5 \times 0.5 \mathrm{~m}$ quadrats failed to intercept them.

Species in Group Ealso tended to increase across outwashplain, moraine-fan and moraine landforms (Plot Groups 2 and 3; Fig. 3). These included tussocks of Poa colensoi and the other indigenous grasses Rytidosperma exiguum (formerly 


\begin{tabular}{|c|c|c|c|c|c|c|c|c|c|c|c|c|c|}
\hline & $j^{2}$ & & lot Gr & up 1 & & & Plot Gr & roup 2 & & & Plot $\mathrm{Gr}$ & roup 3 & \\
\hline $5^{2}$ & 'Species' & RT8 & RT9 & E6 & E7 & OP2 & OP4 & OP5 & OP1 & M10 & M12 & MF3 & M11 \\
\hline $\bar{A}$ & $\begin{array}{l}\text { Anthoxanthum odoratum } \\
\text { Lichen }\end{array}$ & $\begin{array}{l}+ \\
+\end{array}$ & $\begin{array}{l}+ \\
+\end{array}$ & $\begin{array}{l}+ \\
+\end{array}$ & $\begin{array}{l}- \\
+\end{array}$ & $\begin{array}{l}+ \\
+\end{array}$ & + & $\begin{array}{l}- \\
+\end{array}$ & $\begin{array}{l}+ \\
+\end{array}$ & $\begin{array}{l}+ \\
-\end{array}$ & $\begin{array}{l}+ \\
+\end{array}$ & $\begin{array}{l}+ \\
+\end{array}$ & $\begin{array}{l}+ \\
+\end{array}$ \\
\hline B & $\begin{array}{l}\text { Pilosella officinarum } \\
\text { Muehlenbeckia axillaris }\end{array}$ & $\begin{array}{l}+ \\
+\end{array}$ & $\begin{array}{l}+ \\
+\end{array}$ & + & + & $\begin{array}{l}+ \\
+\end{array}$ & + & $\begin{array}{l}+ \\
+\end{array}$ & - & + & - & - & - \\
\hline C & $\begin{array}{l}\text { Carex breviculmis } \\
\text { Leucopogon nanum } \\
\text { Stackhousia minima } \\
\text { Elymus falcis }\end{array}$ & & + & - & - & $\begin{array}{l}+ \\
+ \\
+ \\
+\end{array}$ & $\begin{array}{l}+ \\
+ \\
+ \\
+\end{array}$ & $\begin{array}{l}+ \\
+ \\
+ \\
+\end{array}$ & $\begin{array}{l}- \\
+ \\
- \\
+\end{array}$ & & & - & \\
\hline D & $\begin{array}{l}\text { Festuca novae -zelandiae } \\
\text { Celmisia gracilenta } \\
\text { Geranium brevicaule }\end{array}$ & & & + & - & $\begin{array}{l}+ \\
-\end{array}$ & $\begin{array}{l}+ \\
+ \\
-\end{array}$ & $\begin{array}{l}+ \\
+ \\
-\end{array}$ & $\begin{array}{l}+ \\
+ \\
+\end{array}$ & & & $\begin{array}{l}+ \\
+ \\
+\end{array}$ & \\
\hline$E$ & $\begin{array}{l}\text { Rytidosperma exiguum } \\
\text { Wahlenbergia albo -marg. } \\
\text { Coprosma petriei } \\
\text { Poa colensoi } \\
\text { Pimelea oreophila } \\
\text { Rytidosperma pumila } \\
\text { Agrostis capillaris }\end{array}$ & & - & - & + & $\begin{array}{l}+ \\
- \\
+ \\
+ \\
+ \\
+\end{array}$ & $\begin{array}{l}+ \\
+ \\
+ \\
- \\
- \\
+\end{array}$ & $\begin{array}{l}+ \\
+ \\
+ \\
+ \\
- \\
- \\
+\end{array}$ & $\begin{array}{l}+ \\
+ \\
- \\
+ \\
+ \\
+ \\
+\end{array}$ & $\begin{array}{l}+ \\
+ \\
-\end{array}$ & $\begin{array}{l}+ \\
+ \\
+\end{array}$ & $\begin{array}{l}+ \\
+ \\
+ \\
+ \\
+ \\
+\end{array}$ & $\begin{array}{l}+ \\
+ \\
+ \\
+ \\
+ \\
+\end{array}$ \\
\hline $\mathrm{F}$ & $\begin{array}{l}\text { Leucopogon fraseri } \\
\text { Helichrysum filicaule } \\
\text { Raoulia parkii }\end{array}$ & & & - & & - & - & $\begin{array}{l}- \\
-\end{array}$ & $\begin{array}{l}- \\
-\end{array}$ & $\begin{array}{l}+ \\
+\end{array}$ & - & $\begin{array}{l}+ \\
+ \\
+\end{array}$ & $\begin{array}{l}+ \\
+\end{array}$ \\
\hline G & $\begin{array}{l}\text { Agrostis muscosa } \\
\text { Poa pratensis } \\
\text { Poa lindsayi } \\
\text { Myosotis discolor }\end{array}$ & $\begin{array}{l}- \\
-\end{array}$ & $\begin{array}{l}- \\
- \\
-\end{array}$ & - & - & - & - & $\begin{array}{l}- \\
-\end{array}$ & - & - & - & - & \\
\hline & $\begin{array}{l}\text { Veronica arvensis } \\
\text { Erophila verna } \\
\text { Stellaria gracilenta } \\
\text { Poa maniototo }\end{array}$ & $\begin{array}{l}- \\
- \\
-\end{array}$ & $\begin{array}{l}- \\
- \\
-\end{array}$ & $\begin{array}{l}- \\
- \\
- \\
-\end{array}$ & & $\begin{array}{l}- \\
- \\
-\end{array}$ & $\begin{array}{l}- \\
- \\
-\end{array}$ & $\begin{array}{l}- \\
- \\
-\end{array}$ & $\begin{array}{l}- \\
- \\
-\end{array}$ & - & - & & + \\
\hline $\mathrm{H}$ & $\sim$ & & & & & & & & & & & & \\
\hline & $\begin{array}{l}\text { Trifolium arvense } \\
\text { Aira caryophyllea }\end{array}$ & & & - & $\begin{array}{l}- \\
-\end{array}$ & & $\begin{array}{l}+ \\
+\end{array}$ & + & $\begin{array}{l}+ \\
-\end{array}$ & - & & + & + \\
\hline & $\begin{array}{l}\text { Rumex acetosella } \\
\text { Moss }\end{array}$ & - & - & $\begin{array}{l}+ \\
-\end{array}$ & $\begin{array}{l}- \\
-\end{array}$ & + & + & + & - & $\begin{array}{l}+ \\
-\end{array}$ & - & $\begin{array}{l}+ \\
-\end{array}$ & $\begin{array}{l}+ \\
+\end{array}$ \\
\hline & Pilosella praelta & + & + & + & + & + & & - & - & - & - & + & + \\
\hline
\end{tabular}

Figure 3. Change classification showing Plot Groups 1 to 3 and plots (columns) and Species Groups (A to H) and 'species' (rows), grouped on the basis of similar changes (1993 to 2011) in 12 original vegetation plots in Lake Tekapo Scientific Reserve sampled using the eight-quadrat method. For clarity, cell entries show only change direction (plus for increase and minus for decrease) in the 36 most frequently encountered plant species. $\sim$ indicates that 38 less-common plant species in this group are not shown. Landforms are distinguished by different plot prefixes - RT (river terrace), E (escarpment), OP (outwash plain), $\mathrm{M}$ (moraine), and MF (moraine fan) - and plots are distinguished by label suffixes 1 to 12 . Bold type indicates indigenous species. Wahlenbergia albo-marginata is abbreviated.
Pyrranthera exigua) and $R$. pumilum, the indigenous herb Wahlenbergia albomarginata, the subshrubs Coprosma petriei and Pimelea oreophila, among which the maximum increase was $5.5 \%$, and median change $1.1 \%$ from a median initial cover of $0.04 \%$. Species Group E also included the exotic grass Agrostis capillaris (browntop), in which median cover increased from $2.9 \%$ to $9.5 \%$ between 1993 and 2011. Species Group F distinguishes three indigenous herbs (Helichrysum filicaule, Leucopogon fraseri and Raoulia parkii) that increased on the two most productive landforms, the moraine and moraine fan (plot group 3; maximum increase $0.3 \%$ cover and median change $0.01 \%$ ), and decreased on the outwash plain (plot group 2 ; maximum decrease $-2.5 \%$, median change $-0.03 \%$ cover).

Plots on the arid river-terrace and escarpment (Plot Group 1) shared increases in two hawkweed species (from $0.4 \%$ to $14.8 \%$ and $0.0 \%$ to $0.9 \%$ median cover in Pilosella officinarum and P. praelta, respectively) and the indigenous subshrub Muehlenbeckia axillaris (from $<0.1 \%$ to $0.8 \%$ median cover) (Fig. 3). Whereas increases in non-vascular cover were consistent and substantial (from $8 \%$ to $33 \%$ ), other changes in vascular plants on these landforms were idiosyncratic, reflecting chance interceptions of sparsely-occurring species by the eight small quadrats. Indigenous grasses showed a net increase in quadrats in some plots (for example, Anthosacne falcis in one river terrace plot, and tussocks of Festuca novae-zelandiae and Poa colensoi in different plots on the escarpment) but local dieback of portions of Raoulia australis cushions and shrubs of Melicytus alpinus and Rosa rubiginosa, in individual quadrats accounted for much of the residual observed change.
Changes in life-form groups along a productivity gradient Indigenous tussock grasses showed a pattern of greater increases on more productive landforms, with the largest positive log change ratios (LCRs) on the moraine fan (Fig. 4). Conversely, LCRs for indigenous mat-forming subshrub species and lichens were more positive on more arid and less productive landforms. Species of 'other' indigenous grasses increased widely with little evident landform-associated trend. Indigenous dicot herbs tended to decrease in cover on the river terrace and escarpment, but showed no consistent pattern of change elsewhere. Exotic perennial non-composite herbs showed modest decreases on drier landforms and minor increases on the more productive moraine and moraine fan. Consistently negative LCRs reflect widespread decreases in indigenous dwarf xerophytic grasses and annual exotic herbs. Indigenous dwarf grasses decreased proportionally more on the less productive landforms where they were initially more abundant, but changes in annual exotic herbs showed no clear landform-associated pattern.

\section{Changes in exotic cover along productivity and hawkweed- invasion gradients}

Exotic grasses and hawkweeds showed contrasting patterns of change across the landform productivity gradient, with negative exotic grass LCRs and positive hawkweed LCRs on the least productive landforms, and the reverse on more productive landforms (Figs 4 \& 5). Trends in exotic grasses and hawkweed also varied with initial levels of hawkweed 
(a) Indigenous grass groups

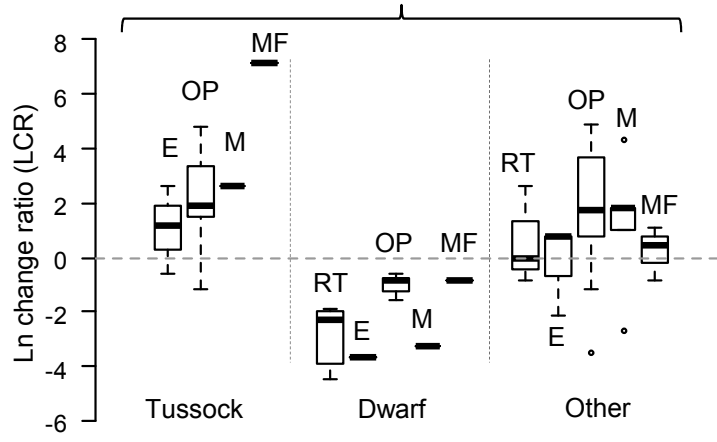

(c) Indigenous dicot herb groups

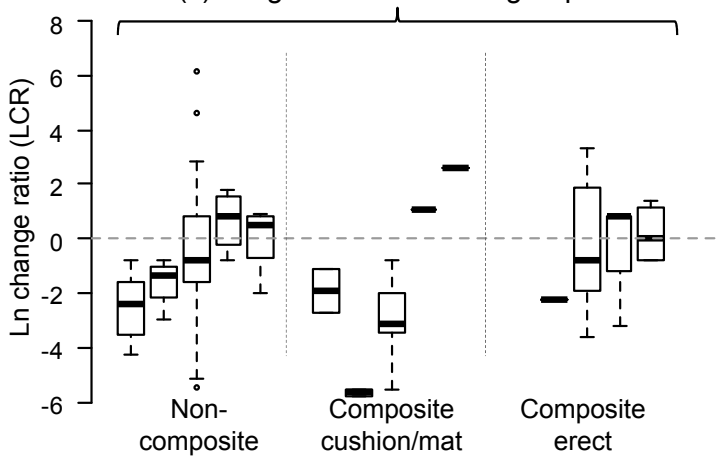

(e) Non-vascular groups

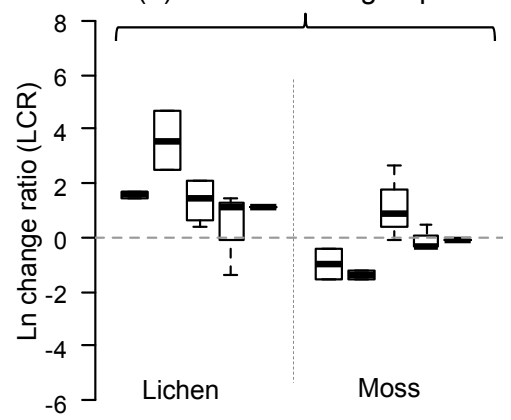

(b) Indigenous shrub groups

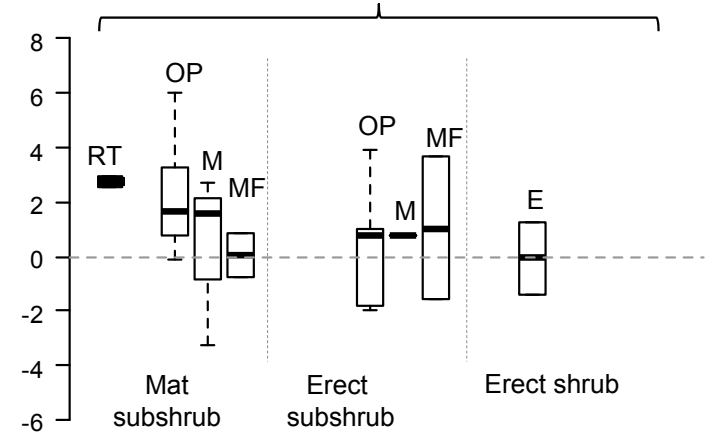

(d) Indigenous non-grass monocot herb groups

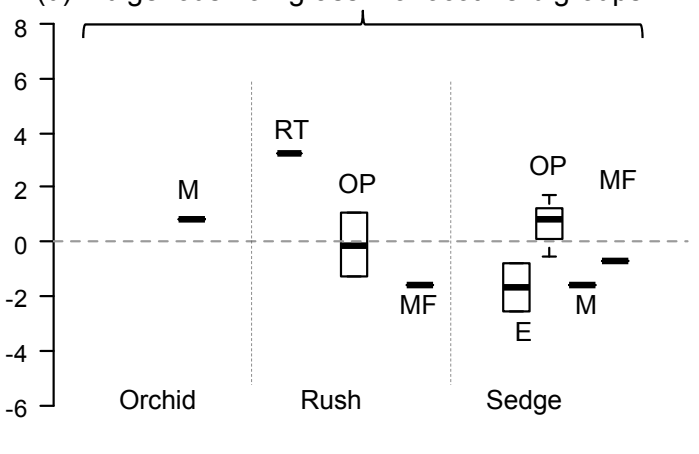

(f) Exotic life-form groups

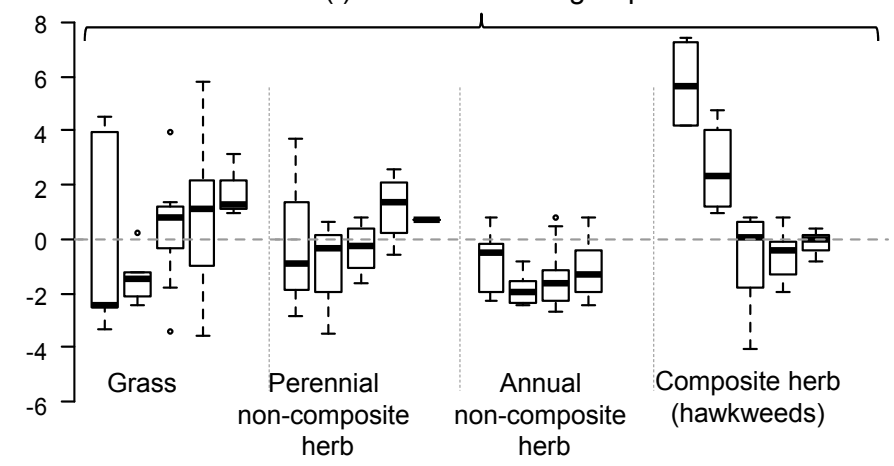

Figure 4. Log change ratios (LCRs) of indigenous (a-e) and exotic (f) plant life-form groups in vegetation plots on the five landforms of Lake Tekapo Scientific Reserve from 1993, soon after mammalian grazing was removed, and 2011. Values below zero (horizontal dashed line) indicate decrease, and those above indicate an increase. The five landforms are, in order of increasing productivity and decreasing soil aridity, from left to right: river terrace (RT), escarpment (E), outwash plain (OP), moraine (M), and moraine fan (MF). Horizontal bold lines are median values, boxes and whiskers show the interquartile range and interdecile ranges, respectively, and points show values outside the interdecile range. A missing plot indicates no species in the plant group was recorded in either year.

cover (Fig. 5). Hawkweed cover increased most on the driest landforms, where it was initially least abundant; increased less on the outwash plain, where its invasion was initially more advanced; and decreased on the most productive moraine and moraine fan, where its invasion was initially most complete (Fig. 5a). Exotic grass cover increased most markedly where hawkweed cover was initially greatest (Fig. 5b).

\section{Changes in recovery indicators along productivity and hawkweed-invasion gradients}

Our six recovery indicators show a widespread recovery of indigenous vegetation from grazing between 1993 (soon after mammalian grazing was removed) and 2011 in LTSR. Exposed soil and rock decreased, and litter and total indigenous cover increased through time on all landforms (Fig. 6a, b, d). Neither landform productivity nor initial hawkweed cover evidently affected these trends: year $\times$ productivity and year $\times$ initial hawkweed interaction effects in these models were non-significant (i.e. all 95\% HPDI included zero). In contrast, recovery of indigenous tussock cover, vascular indigenous cover and indigenous cover dominance were greater on more productive landforms, and also on landforms where initial hawkweed cover was higher (indicated by significant interaction effects; Fig. 6c, e, f). The relative importance of 
(a) Hawkweed cover

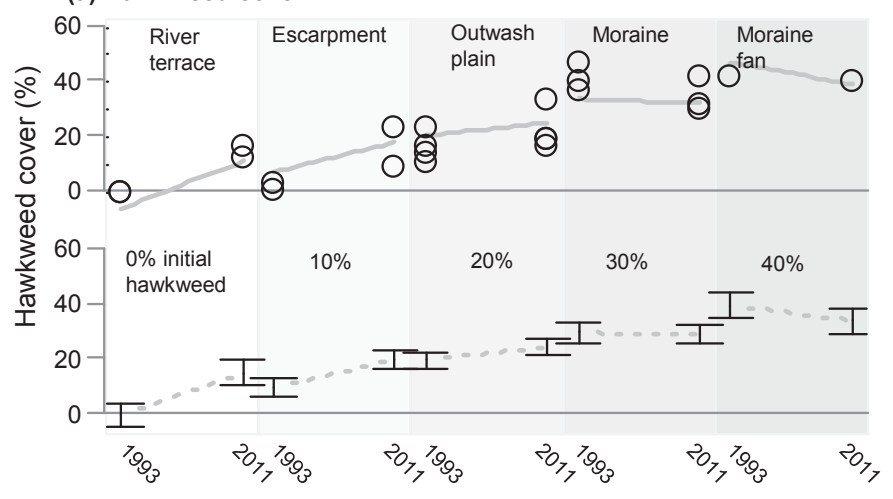

(b) Exotic grass cover

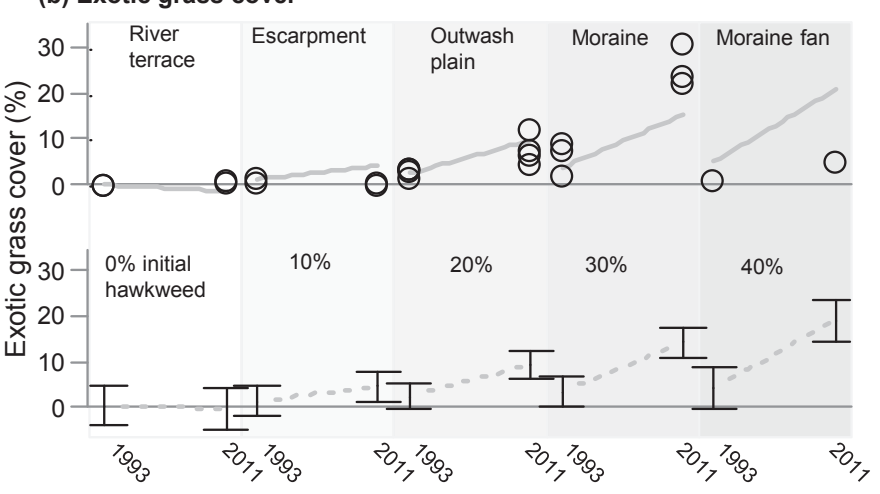

Figure 5. Modelled effects (averaged over other terms in the model) on (a) hawkweed and (b) exotic grass cover in the 12 original plots in Lake Tekapo Scientific Reserve that were sampled using the eight-quadrat method in 1993, soon after mammalian grazing was removed, and in 2011. In the upper plots in each pair, grey solid lines show effects of time on the response variable with increasing productivity rank (indicated by changes in background shading), and the unfilled points show observed values on the different landforms (which are labelled). In lower plots, grey dashed lines show effects of time at different levels of initial hawkweed cover (indicated by changes in background shading and labels showing the percentage), and error bars show $95 \%$ confidence intervals of the modelled effects. Interactions between the predictor and year were statistically significant at $P<0.05$ in all four models.

the two collinear predictors - productivity rank and initial hawkweed cover - could not be established with these data.

Tussock cover was negligible on all landforms in 1993, and by 2011 had increased on the moraine fan and outwash plain but changed little on the river terrace, escarpment and moraine (Fig. 6c). Indigenous vascular plant cover was lowest on the moraine and river terrace in 1993, and in 2011 had increased on the three most productive landforms (moraine fan, moraine and outwash plains) but decreased on the two driest landforms (river terrace and escarpment) (Fig. 6e). Indigenous cover dominance decreased on the least productive landforms where it had been initially highest, and increased on the three more productive landforms (outwash plain, moraine and moraine fan) where it was initially lowest (Fig. 6f).

\section{Discussion}

\section{Post-pastoral vegetation change}

Indigenous vegetation in LTSR recovered generally following removal of mammalian grazing in 1992, indicated by widespread decreases in bare ground and exposed rock, annual species, and diminutive xerophytic indigenous dwarf grasses, and increases in taller palatable perennial species. These trends resemble the types of successional shifts initiated by grazing-release that are often recorded in other countries, and are thought to reflect trade-offs in plants between traits that lower losses to herbivory and those that result in superior competitive ability for resources or space (Huntly 1991).

Productivity appeared to hasten indigenous recovery of vascular plant cover. On more productive landforms in LTSR, taller perennial vascular plants previously held in check by grazing (indigenous tussocks, and a variety of other grasses, subshrubs and herbs) increased more rapidly and were proving superior competitors to hawkweed under low grazing pressure. These changes are consistent with a switch from dominance by plant life forms that tolerate grazing to those that compete well for light in the absence of grazing (Milchunas et al. 1988; Olff \& Ritchie 1998). On drier landforms (escarpment and river terrace) indigenous lichens and mat shrubs increased simultaneously with hawkweed while taller species (especially exotic grasses and tussock grasses) showed little change, consistent with greater resource limitation constraining regrowth of taller vascular species. Here, grazing-release appears to have favoured stress-tolerant plants that compete well for nutrients and water in the absence of herbivory (including indigenous lichens and subshrubs) rather than in its presence (e.g. exotic annual and xerophytic indigenous dwarf grass and herb species, which were more abundant in 1993) and before competition for light has developed.

Our results are clearly inconsistent with the hypothesis that hawkweed cover retards indigenous vegetation recovery. To the contrary, we found significantly greater vascular plant recovery where hawkweed cover was higher at the time mammalian grazing was removed. Because initial hawkweed cover and landform productivity rank were confounded by hawkweed's earlier invasion of more productive landforms, we cannot discriminate between the alternatives that hawkweed had negligible effect on recovery, or positively facilitated it. Both are possible. The importance of positive plant-plant interactions (facilitation) increases relative to negative interactions (e.g. competition) in high-stress environments (Bertness \& Callaway 1994; Callaway 2007), and the reserve's severe environment limits biomass production through cold winters, short summers, high seasonal moisture stress, and soil fertility that is 'not particularly high' (Webb 1992). Although glasshouse transplant trials show negative competitive effects of hawkweed on indigenous species (e.g. Moen \& Meurk 2001), in ungrazed field conditions hawkweed could potentially aid establishment and growth of more-palatable species through mechanisms such as stabilisation of frost-heaved soils or shelter from desiccation.

Whether or noteffects of hawkweed on recovery are positive or neutral, its performance under conservation management in our study is consistent with classical expectations of a plant that is prostrate-growing and light-demanding, with low palatability (Grime \& Jeffrey 1965; Gaudet \& Keddy 1988; Moen \& Meurk 2001; Rose et al. 2004). Hawkweed appears well adapted to grazing and stock trampling in this grassland system, but was a weak competitor for light with species in taller 
(a) Exposed soil and rock
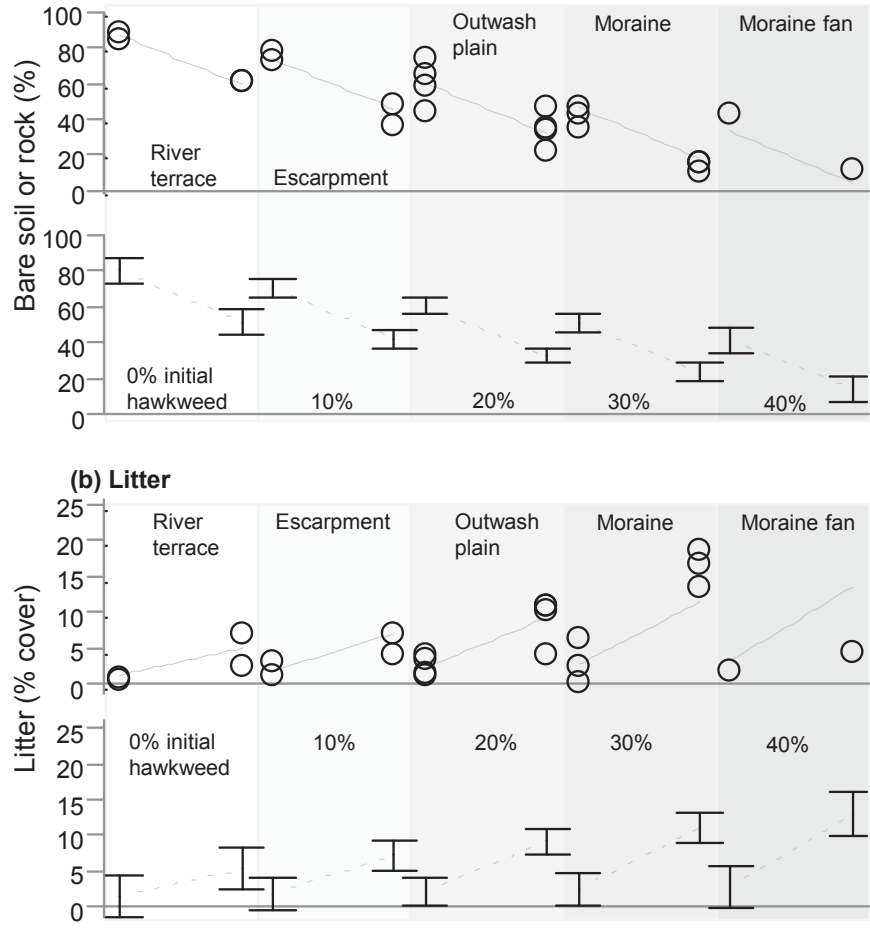

(c) Indigenous tussock

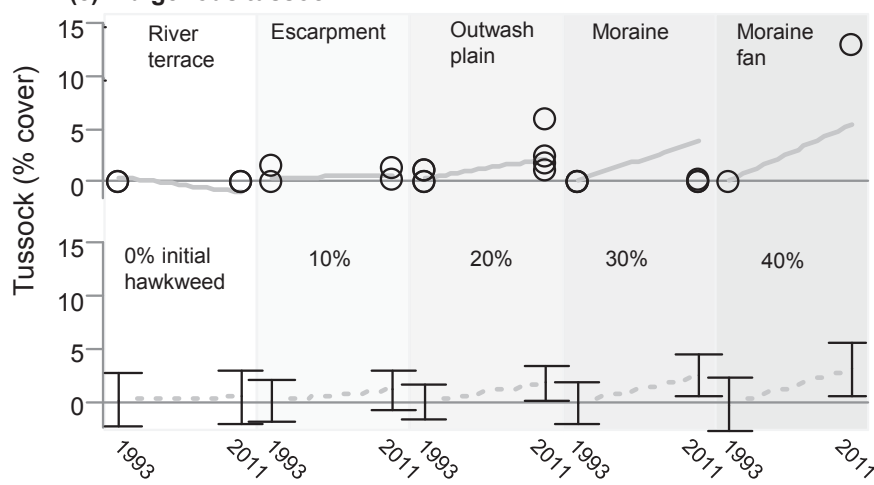

(d) Total indigenous cover (vascular + non-vascular)

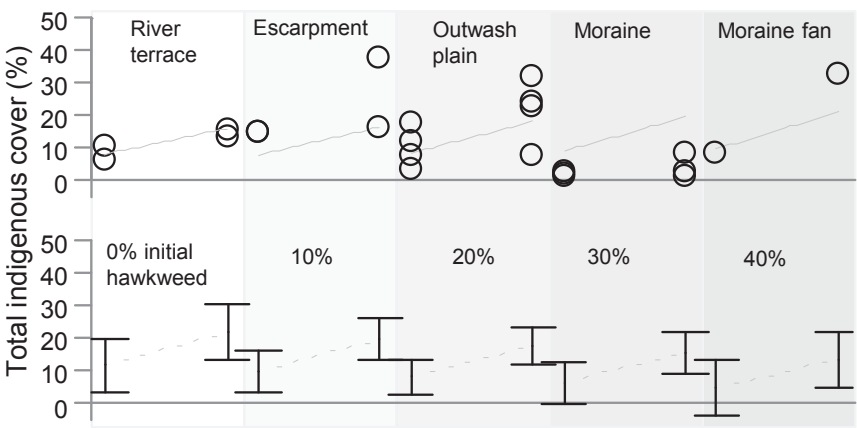

(e) Vascular indigenous cover

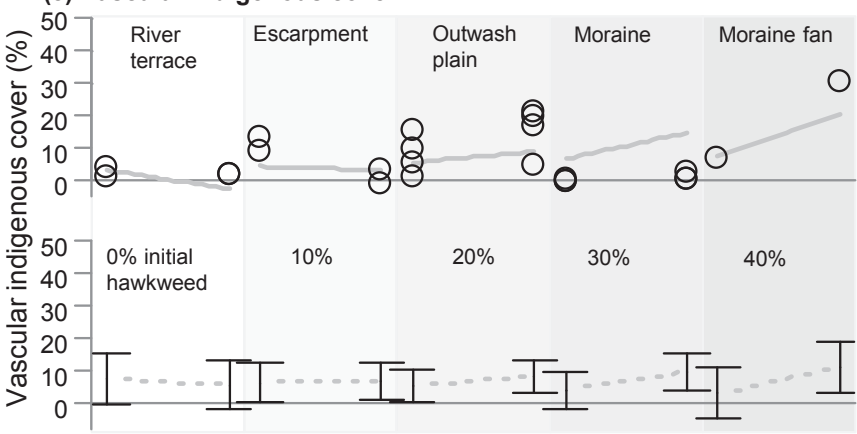

\section{(f) Indigenous cover dominance}

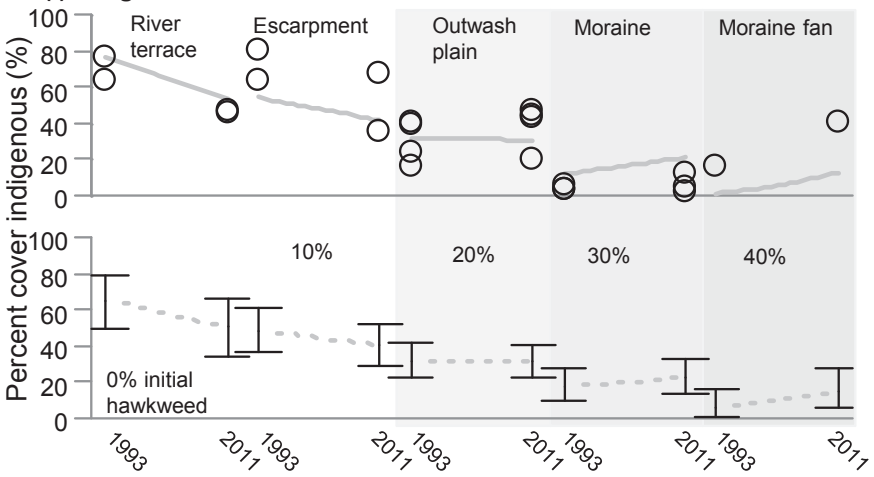

Figure 6. Modelled effects (averaged over other terms in the model) on six recovery indicators in the 12 original plots in Lake Tekapo Scientific Reserve that were sampled using the eight-quadrat method in 1993, soon after mammalian grazing was removed, and in 2011. In the upper plots in each pair, grey lines show the modelled effects of time on the response variable with increasing productivity rank (indicated by changes in background shading), and unfilled points show observed values on the different landforms (which are labelled). In lower plots of each pair, grey dashed lines show the modelled effect of time at different levels of initial hawkweed cover, and the error bars show 95\% confidence intervals of the modelled effects. Heavy lines in (c), (e) and (f) indicate that interaction between the predictor and year was statistically significant at $P<0.05$ in those models, and therefore changes varied with levels of productivity (upper plots) or initial hawkweed (lower plots).

and more palatable plant groups. The recovery of indigenous vegetation despite substantial initial hawkweed cover on some landforms also supports the hypothesis that grassland degradation is a symptom of past grazing management (e.g. Treskonova 1991), rather than the notion that hawkweed is an aggressive competitor (Scott 1985).

\section{A model of vegetation recovery}

Acknowledging the limitations of our study and data as set out in the Methods section, we apply our results to propose, as a hypothesis, a conceptual model of vegetation recovery (Fig. 7) that compares and combines our results with predictions founded on ecological trade-offs in plants. Specifically, our model predicts that, in more productive sites, release of palatable plants from asymmetric grazing-suppression (Louda et al. 1990; Huntly 1991) will result in suppression of unpalatable and low-growing species (including mouseear hawkweed) through the restoration of above-ground competition for light (lower to upper right in Fig. 7; Tilman 1988; see also Laliberté et al. 2013). Where resource limitation constrains growth and population densities, and competition is weak and largely below-ground, protracted coexistence of palatable and unpalatable stress-tolerant plants is predicted (lower to upper left Fig. 7). However, coexistence may be less protracted if the initial post-grazing colonists of dry landforms facilitate succession to taller life forms through positive plantplant interactions (e.g. Callaway 1997). 
(a)

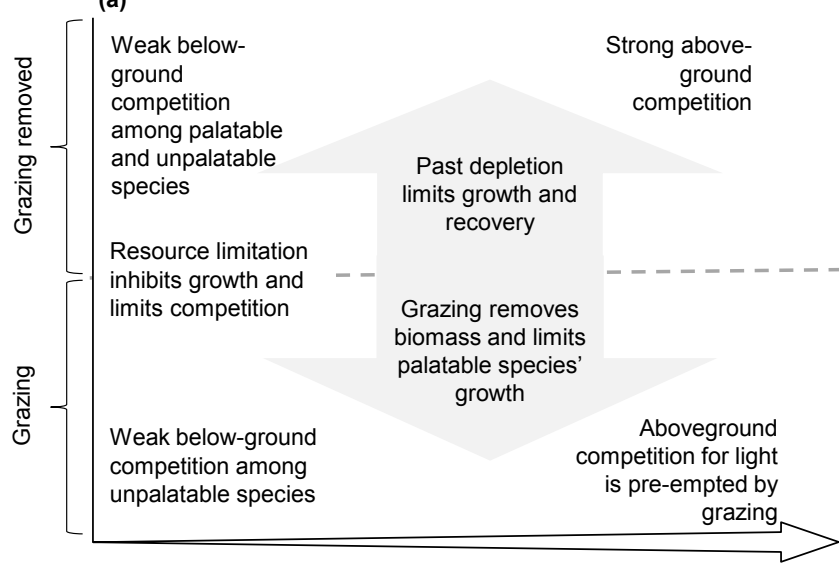

(b)

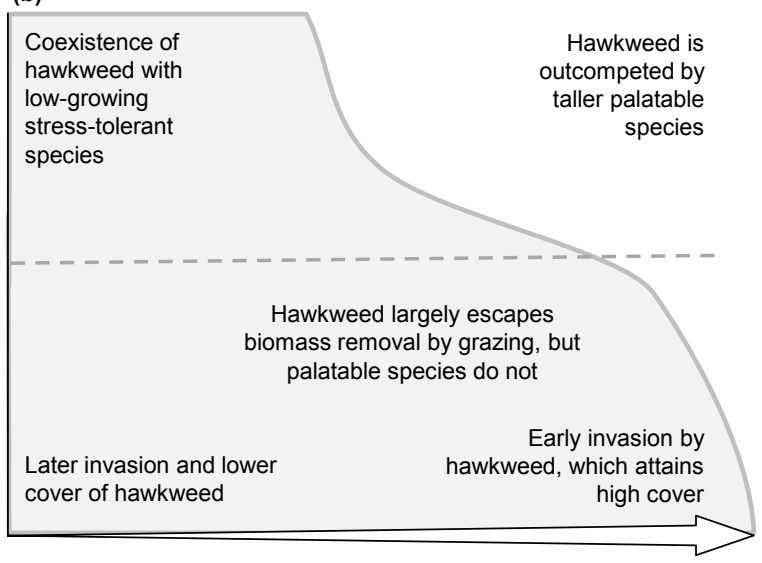

INCREASING PRODUCTIVITY, DECREASING STRESS (ARIDITY)

Figure 7. Conceptual model of the influence of a stress-productivity gradient (horizontal axis) and competition (mediated by grazing and its removal, vertical axis) on recovery of indigenous grassland vegetation (a) and the niche of hawkweed (b) on the Upper Waitaki Basin floor. The grey area in (b) indicates the realised niche of hawkweed.

On sites that experience the highest stress, the model suggests non-vascular rather than vascular plant cover may be first to recover from grazing. Biological crusts comprising lichens, cyanobacteria, algae, microfungi, and mosses have been little investigated in New Zealand (Ullmann et al. 2007), but are common on arid and recent surfaces worldwide, and are known to play important ecological roles in ground consolidation and succession and to be vulnerable to stock trampling and grazing (Belnap \& Lange 2001; Michel et al. 2013). Conspicuous increases in non-vascular crust on drier surfaces in LTSR after 1993 suggest pastoral land use may constrain their development on drier landforms of New Zealand's inland South Island basins that are too severe for rapid development of taller vegetation. Furthermore, cessation of grazing may assist their recovery.

\section{Niche and role of hawkweed in vegetation recovery}

Figure 7b shows our model's implications for the invasion and persistence of hawkweed. Unpalatable, light-demanding hawkweed is affected mainly indirectly by grazing through herbivore-suppression of palatable species (e.g. van der Wal et al. 2000). However, productivity affects hawkweed both directly, through controlling its rate of establishment and the cover it may attain (Duncan et al. 1997), and indirectly, through controlling the importance and type of competition or facilitation (Tilman 1988; Callaway 1997).

Other conceptual models of New Zealand tussock grassland systems have proposed factors governing hawkweed invasion (e.g. Duncan et al. 1997; Rose et al. 1998). Duncan et al. (1997) suggest that past management (through its effects on vegetation physiognomy), environment (through the retarding effects of moisture stress) and propagule pressure combine to predict hawkweed invasion. However, they propose that invasion is also a matter of timing, because hawkweed propagule pressure in a region eventually becomes sufficient that all sites inevitably end up with levels of hawkweed that are predictable from environmental conditions alone. Duncan et al. (1997) suggested that the propagule-saturation stage had been reached by the early 1990s in the Upper Waitaki Basin. Our model concurs, but also considers effects of productivity, and hence competition, in moderating the eventual cover of hawkweed following release from grazing (i.e. upper panel in Fig. 7b). In particular, we incorporate the changes observed on the moraine and moraine fan landforms in LTSR, and predict that competition for light will develop and reduce hawkweed cover on more productive landforms.

Our model's predictions are more similar to those of Duncan et al. (1997) on drier landforms where competition for light is expected to be weak and to develop slowly following grazing-release. Both models predict that aridity will constrain the rate of invasion and potential cover of hawkweed, and our model predicts that grazing cessation will exert little influence on vegetation in low-productivity sites for some considerable time. We therefore interpret increases in hawkweed cover on the dry LTSR escarpment and river terrace between 1993 and 2011 to reflect the timing of hawkweed's progression onto the basin floor's driest landforms in the early 1990s, which was regulated by aridity and regional propagule pressure, and little affected by recent management. This interpretation is supported by the timing of invasions, and the relative levels of cover attained by hawkweed, across four short-tussock grassland sites on outwash plains in the Mackenzie Basin Grazing Trial (MBGT) in the 1990s (Meurk et al. 2002). In the MBGT, hawkweed had invaded deeper, more productive soils of the Fork and Pukaki/Holbrook series by 1990 , but was rare in the two sites on drier Mackenzie series soils. Hawkweed invaded these drier MBGT sites between 1990 and 2000 despite a substantial decrease in grazing pressure over that decade under the Rabbit and Land Management Programme (Meurk et al. 2002). To date, hawkweed's increases on the escarpment and river terrace landforms in LTSR have been notably slower ( $<1 \%$ cover increase per annum from 1993 to $2011 \mathrm{vs}>3 \%$ per annum from 1990 to 2000) and less comprehensive (reaching $15-16 \%$ cover) than on the somewhat less arid Mackenzie soils on two outwash plains in the MBGT, where $35-45 \%$ cover was attained by 2000 .

An outcome of weak competitive interactions in highstress environments and the stronger competition for light in productive environments in our model is that the niche of hawkweed is progressively constrained to higher-stress environments following grazing-release (shown as the grey area in Fig. 7b). It also follows that the invasion or presence 
of hawkweed should have little negative influence on postgrazing recovery of palatable plant species across the entire productivity gradient. This is because competition is a weak and relatively inconsequential force on the dry, high-stress landforms where hawkweed could potentially compete successfully for soil resources, and hawkweed is poorly equipped to compete for light on productive landforms. In our results, these predictions are borne out by simultaneous increases in the cover of lichens and indigenous subshrubs as hawkweed invaded the drier landforms of LTSR after 1993, and by decreases in hawkweed cover as taller palatable plants increased on more productive landforms.

\section{Why do outcomes at LTSR differ from those in other studies?}

Changes recorded in LTSR suggest release of heavilyhawkweed-invaded, highly-modified short-(fescue)-tussock grasslands from pastoral grazing can result in indigenous vegetation recovery through predictable successional changes. These results contrast with findings in other studies (e.g. Rose et al. 1995; McIntosh \& Allen 1998; Meurk et al. 2002; Rose \& Frampton 2007), and several factors may explain this divergence.

First, conservation management in LTSR has maintained both a complete absence of stock and very low levels of grazing by feral herbivores (in particular, rabbits) since the reserve's inception, likely reducing offtake of indigenous species' biomass to lower levels than merely retirement from sheep grazing (e.g. Rose et al. 1995). Second, in LTSR low grazing levels have been maintained over an extensive area $(>1000$ ha) rather than in small exclosures (e.g. half a hectare or less in the studies of McIntosh \& Allen (1998), Meurk et al. (2002) and Rose \& Frampton (2007)). Small exclosures can potentially limit key ecological recovery processes, such as the accumulation of seed sources or microclimate amelioration, or fail to incorporate the local heterogeneity of microclimates that provide refuges from extreme events such as droughts (Keppel et al. 2012).

Athird difference may lie in the comparatively low levels of human disturbance of the vegetation ofLTSR, where resampling was permitted only twice (in 1995 and 2009) in the 18 years before our survey. Exclosure studies of Rose and Frampton (2007) and Meurk et al. (2002) were measured annually or at least 2-yearly over a decade, which Dickinson (1992) suggested was 'excessive'. Indigenous vascular plants evolved without large-hooved mammals (Mack \& Thompson 1982), cryptogam crusts are known to be susceptible to trampling (Belnap \& Lange 2001), and we would expect hawkweed to be better adapted to the effects of crushing, scuffing, and soil compaction that accompany vegetation sampling. If regular resampling cumulatively favours hawkweed relative to indigenous plant cover, the effect might overwhelm more subtle effects of grazing treatments. This idea should be amenable to field testing, and to a literature review comparing sampling frequencies and reported grassland trends across multiple studies.

A final factor differentiating our study is timing. LTSR was released from grazing after indigenous species' cover had already declined to low levels $(<1 \%)$ and hawkweed invasion had largely run its course on the three main landforms (its cover decreased from high levels on the moraine and moraine fan, and increased only slightly on the outwash plain where it was initially moderately abundant). Other studies have spanned periods of simultaneous decline in indigenous cover (especially of visually conspicuous indigenous tussocks) and increases in hawkweed. They have either concluded a causal relationship between temporally coincident observations (Rose \& Frampton 2007) or been unable to rule out that possibility (Rose et al. 1995; Meurk et al. 2002). By demonstrating that hawkweed has limited ability to outcompete indigenous species in the absence of grazing, changes at LTSR resolve the confounding of correlation with causation and suggest that indigenous cover depletion and hawkweed invasion are both consequences of other, long-term, landscape-scale drivers.

\section{Implications for management and research}

Outcomes of conservation management in LTSR suggest hawkweed invasion is unlikely to be an impediment to the recovery from grazing of highly depleted short-tussock grasslands and herbfields on the floor of the Upper Waitaki Basin. Indeed, hawkweed cover may facilitate recovery, or its effects may be merely neutral. Recovery of the indigenous vegetation component from grazing appears possible despite very advanced levels of depletion of indigenous vegetation cover $(<1 \%)$ and high initial levels of hawkweed invasion $(>40 \%)$. Increases in vascular indigenous vegetation occur more rapidly on more productive landforms, although recovery of indigenous tussock physiognomy may take decades where indigenous cover and seed sources have been severely depleted. Non-vascular plant cover may increase first on more arid landforms and soils, where the growth of indigenous vascular plant species is inherently slower.

Conservation management in LSTR has maintained all grazing mammals at particularly low levels across a large area since 1992, and our results do not show whether recovery can be achieved with smaller reductions in grazing pressure or at smaller scales. Research across multiple protected areas of short-tussock grassland is needed to determine the effects of scale, residual levels of mammalian herbivores, and repeated monitoring-disturbance on the recovery of short-tussock grassland.

\section{Acknowledgements}

This study was undertaken as a partnership between the Dryland Intermediate Outcome research programme funded by the Ministry of Business, Innovation and Employment (formerly the Foundation for Research, Science and Technology; Contract C09X0503) and the Department of Conservation, and our data are to be lodged in NVS (the National Vegetation Survey databank). We are grateful to C. Woolmore and A. Ghameghamy for assistance in the field, to J. Overton for sampling advice, to B. Anderson, A. Brandt, A. Monks, and W. Lee for helpful comments and discussion, and to J. Tylianakis, A. Mark, and an anonymous reviewer for constructive comments on a draft.

\section{References}

Allen RB, Rose AB, Evans GR 1983. Grassland survey manual: a permanent plot method. New Zealand Forest Research Institute Bulletin no 43. $71 \mathrm{p}$.

Barrell DJA, Andersen BG, Denton GH 2011. Glacial geomorphology of the central South Island, New Zealand. GNS Science Monograph 27. Lower Hutt, GNS Science. $81 \mathrm{p}$.

Belnap J, Lange OL eds 2001. Biological soil crusts: structure, function, and management. Ecological Studies 150. New 
York, Springer. 503 p.

Bertness MD, Callaway R 1994. Positive interactions in communities. Trends in Ecology and Evolution 9: 191-193.

Callaway RM 1997. Positive interactions in plant communities and the individualistic-continuum concept. Oecologia 112: $143-149$.

Callaway RM 2007. Positive interactions and interdependence in plant communities. Dordrecht, The Netherlands, Springer. $415 \mathrm{p}$.

D'Antonio C, Meyerson LA 2002. Exotic plant species as problems and solutions in ecological restoration: a synthesis. Restoration Ecology 10: 703-713.

Davies KF, Harrison S, Safford HD, Viers JH 2007. Productivity alters the scale dependence of the diversity-invasibility relationship. Ecology 88: 1940-1947.

Day NJ, Buckley HL 2013. Twenty-five years of plant community dynamics and invasion in New Zealand tussock grasslands. Austral Ecology 38: 688-699.

Dickinson KJM 1992. Monitoring changes in non-forest ecosystems: case studies from Molesworth Station and the Mackenzie (Waitaki) basin. In: Hunter GG, Mason $\mathrm{CR}$, Robertson DM eds Vegetation change in tussock grasslands with emphasis on hawkweeds. Occasional Publication 2. Christchurch, New Zealand Ecological Society. Pp. 39-43.

Duncan RP, Colhoun KM, Foran BD 1997. The distribution and abundance of Hieracium species (hawkweeds) in the dry grasslands of Canterbury and Otago. New Zealand Journal of Ecology 21: 51-62.

Espie PR 1997. Tekapo Scientific Reserve: ecological restoration. Conservation Advisory Science Notes 149. Wellington, Department of Conservation. $26 \mathrm{p}$.

Fox J 2003. Effect displays in R for generalised linear models. Journal of Statistical Software 8: 1-27. http://www. jstatsoft.org/v08/i15/ (accessed 7 September 2015).

Gaudet CL, Keddy PA 1988. A comparative approach to predicting competitive ability from plant traits. Nature 334: 242-243.

Grime JP 1979. Plant strategies and vegetation processes. Chichester, Wiley. 222 p.

Grime JP, Jeffrey DW 1965. Seedling establishment in vertical gradients of sunlight. Journal of Ecology 53: 621-642.

Huntly N 1991. Herbivores and the dynamics of communities and ecosystems. Annual Review of Ecology and Systematics 22: 477-503.

Keppel G, Van Niel KP, Wardell-Johnson GW, Yates CJ, Byrne M, Mucina L, Schut AGT, Hopper SD, Franklin SE 2012. Refugia: identifying and understanding safe havens for biodiversity under climate change. Global Ecology and Biogeography 21: 393-404.

Laliberté E, Lambers H, Norton DA, Tylianakis JM, Huston MA 2013. A long-term experimental test of the dynamic equilibrium model of species diversity. Oecologia 171: 439-448.

Leathwick J, Morgan F, Wilson G, Rutledge D, McLeod M, Johnston K 2003. Land Envrionments of New Zealand: a technical guide. Wellington, New Zealand, Ministry for the Environment and Landcare Research. 237 p.

Legendre P, Legendre L 2012. Numerical Ecology. Amsterdam, Elsevier Science BV.

Louda SM, Keeler KH, Holt RD 1990. Herbivore influences on plant performance and competitive interactions. In: Grace JB, Tilman D eds Perspectives on plant competition. San Diego, CA, Academic Press. Pp. 413-444.
Mack RN, Thompson JN 1982. Evolution in steppe with large, hooved animals. American Naturalist 119: 757-773.

Mark AF, McLennan B 2005. The conservation status of New Zealand's indigenous grasslands. New Zealand Journal of Botany 43: 245-270.

McIntosh PD, Allen RB 1998. Effect of exclosure on soils, biomass, plant nutrients, and vegetation, on unfertilised steeplands, Upper Waitaki District, South Island, New Zealand. New Zealand Journal of Ecology 22: 209-217.

Meurk CD, Walker S, Gibson RS, Espie P 2002. Changes in vegetation states in grazed and ungrazed Mackenzie Basin grasslands, New Zealand, 1990-2000. New Zealand Journal of Ecology 26: 95-106.

Michel P, Payton IJ, Lee WG, \& During HJ 2013. Impact of disturbance on above-ground water storage capacity of bryophytes in New Zealand indigenous tussock grassland ecosystems. New Zealand Journal of Ecology 37: 114-126.

Milchunas DG, Sala OE, Lauenroth WK 1988. A generalized model of the effects of grazing by large herbivores on grassland community structure. The American Naturalist 132: 87-106.

Moen J, Meurk CD 2001. Competitive abilities of three indigenous New Zealand plant species in relation to the introduced plant Hieracium pilosella. Basic and Applied Ecology 2: 243-250.

Olff H, Ritchie ME 1998. Effects of herbivores on grassland plant diversity. Trends in Ecology \& Evolution 13: 261-265.

Plummer M, Best N, Cowles K, Vines K 2006. CODA: Convergence diagnosis and output analysis for MCMC. R News 6: 7-11.

Pyšek P, Jarošík V, Hulme PE, Pergl J, Hejda M, Schaffner U, Vilá M 2012. A global assessment of invasive plant impacts on resident species, communities and ecosystems: the interaction of impact measures, invading species' traits and environment. Global Change Biology 18: 1725-1737.

R Core Team 2014. R: A language and environment for statistical computing. Version 3.10.1. Vienna, Austria, R Foundation for Statistical Computing. http://www.Rproject.org/

Rose AB, Frampton C 2007. Rapid short-tussock grassland decline with and without grazing, Marlborough, New Zealand. New Zealand Journal of Ecology 31: 232-244.

Rose AB, Platt KH, Frampton CM 1995. Vegetation change over 25 years in a New Zealand short-tussock grassland: effects of sheep grazing and exotic invasion. New Zealand Journal of Ecology 19: 163-174.

Rose AB, Basher LR, Wiser SK, Platt KH, Lynn IH 1998. Factors predisposing short-tussock grasslands to Hieracium invasion in Marlborough, New Zealand. New Zealand Journal of Ecology 22: 121-140.

Rose AB, Suisted PA, Frampton CM2004. Recovery, invasion, and decline over 37 years in a Marlborough short-tussock grassland. New Zealand Journal of Botany 42: 77-87.

Scott D 1984. Hawkweeds in run country. Tussock Grasslands and Mountain Lands Institute. Review 42: 33-48.

Tilman D 1988. Plant strategies and the dynamics and structure of plant communities. Monographs in Population Biology 26. Princeton, NJ, Princeton University Press. 360 p.

Treskonova M 1991. Changes in the structure of tall tussock grasslands and infestation by species of Hieracium in the Mackenzie Country, New Zealand. Zealand Journal 
of Ecology 15: 65-78.

Ullmann I, Bannister JM, Bannister P 2007. The Placopsis trachyderma - Raoulia - community, a special type of biological soil crusts in the braided rivers of southern New Zealand. Flora - Morphology, Distribution, Functional Ecology of Plants 202: 687-694.

Van der Wal R, Egas M, Van der Veen A, Bakker J 2000. Effects of resource competition and herbivory on plant performance along a natural productivity gradient. Journal of Ecology 88: 317-330.

Editorial board member: Jason Tylianakis

Received 1 October 2014; accepted 5 September 2015
Walker S, Comrie J, Head N, Ladley KJ, Clarke D, Monks A 2015. Sampling method and sample size affect diversity and indigenous dominance estimates in a mixed grassland community. New Zealand Journal of Ecology 40: $150-159$.

Webb TH 1992. Soils of the Upper Waitaki Basin, South Island, New Zealand. DSIR Land Resources Scientific Report 3. 100 p.

Wiser SK, Rose AB 1997. Two permanent plot methods for monitoring changes in grasslands: a field manual. Lincoln, Landcare Research. 51 p. 